\title{
New Road Infrastructures in Italy: Governance, Coordination and Regional Development-Actual Case: Quadrilatero S.p.A.
}

\author{
Giovanni Capulli \\ University of Macerata, Macerata, Italy \\ Email: g.capulli@unimc.it
}

Received 10 March 2016; accepted 18 April 2016; published 21 April 2016

Copyright (C) 2016 by author and Scientific Research Publishing Inc.

This work is licensed under the Creative Commons Attribution International License (CC BY). http://creativecommons.org/licenses/by/4.0/

\begin{abstract}
This essay is aimed to verify the following statement by an actual case from the Italian experience: when decisions are well coordinated and there is a strong cooperation within the hierarchy, new road infrastructures can solve congestion and at the same time, they can be an important flywheel for the regional economy especially in those regions that have economies export-orientated.
\end{abstract}

\section{Keywords}

\section{Infrastructure Development, Political Geography, Regional Governance}

\section{Introduction}

The process of the construction of road infrastructures in Italy is very articulated: there is a strong hierarchy among level of governance and processes can be really effective only if it is well-coordinated. The construction of new road infrastructures has a fundamental role in the development of the whole Italian economy.

In the first part of this essay, I want to clearly describe processes related to the road infrastructures in the Italian context. The description of processes of the construction of new road infrastructures cannot be separated from a brief analysis of Italian political geography and Italian hierarchy of governance. In the second part, I want to analyze an actual case, very emblematic for its complexity especially if it is aimed to verify the initial statement: Quadrilatero S.p.A. (S.p.A, Società per Azioni, Joint Stock Company) not only is constituted by several authorities both public and private, but there is within it the whole hierarchy of governance related to this field. 


\section{Processes of the Construction of New Road Infrastructures in the Italian Context}

Although Italy is a centralized state, there are strong local authorities. Italian territory is divided in twenty regions, authorities similar to Canadian provinces. Each region is divided in provinces, a legal local government. Currently there is a political debate in Italy about the necessity to abolish provinces. An attempt was made by the outgoing government but it was rejected. However in 2014, provinces of the fourteen most populated Italian cities will be replaced by new fourteen authorities called "città metropolitana" (metropolitan city).

In addition, there is the necessity to explain the hierarchy of municipalities in order to better understand the context. Recalling state, regions and provinces, in Italy there are three levels of capital city. Rome is the capital city of Italy, but in addition, each region has its regional capital (in Italian capoluogo di regione): in Italy there are twenty regional capital. Provinces are 110 and each province has its provincial capital (in Italian capoluogo di provincia): provincial capitals are more than 110 because some province has a dual provincial capital. Provinces (and car plates) are identified by the abbreviation of the name of the province that usually corresponds to the name of the provincial capital city: rarely a province can have two or three provincial capital cities. I provide some examples (description of "Regione Marche" is linked to the second part of this essay) in order to summarize:

- Rome is the capital city of Italy, is the regional capital city of Regione Lazio and the provincial capital city of Provincia di Roma (Provincia di Roma will be abolished in 2014 and replaced by città metropolitana di Roma (metropolitan city of Rome).

- Regione "Marche", regional capital city Ancona.

- Regione "Marche" is divided in 5 provinces identified by their provincial capital cities: Provincia di Ancona (AN), Provincia di Ascoli Piceno (AP), Provincia di Fermo (FM), Provincia di Macerata (MC), Provincia di Pesaro and Urbino (two cities, together, PU).

This description can be useful to understand that despite the centralism, Italy is very fragmented: the theoretical will is to ensure the protection of local identities.

For all these reasons, the most important feature of Italian governance is the complexity and one of the clearest example is the construction of new road infrastructures. Being a centralized country, the state governance has a key role but, as highlighted by Professor Marco Ponti (Ponti, 2005), regions and provinces may oppose and stop any kind of work: the state cannot operate without their consent. The economic effort in new road infrastructures of regions and provinces is lower but they are involved in the identification of areas for the construction of infrastructure and they are involved in the coordination among the enormous number of local municipalities: Italy has 8000 comuni (comune is the Italian word for municipality) in a territory that is a third of the province of Ontario but populated by more than 60 million inhabitants.

Italian road network can be divided in three categories: (mainly toll) highways, national roads and provincial roads. The main actor in the construction of road infrastructures in Italy is the ANAS (Azienda Nazionale Autonoma delle Strade/National Autonomous Roads Corporation), an Italian government-owned company deputed to the construction of Italian highways and national roads. Usually, private companies can become concessionaire on toll highways and ensure the maintenance of them: the largest is Atlantia S.p.A. controlled by the Benetton family. ANAS have a sole partner, the Ministry of Economy and Finance, but the company is also monitored by the Ministry of Transport and Infrastructure. State investments on road infrastructure has to be authorized by the inter-ministerial economic planning body, Comitato Interministeriale per la Programmazione Economica_CIPE, which has the final say on them (Beria et al., 2010). Even if the role of ANAS remains fundamental:

“After the promulgation of the Decree 112/9810 the Italian Government transferred the authority for administrating national roads from ANAS to the local governments (Regioni); provincial roads are actually managed by the second level of local governments (Province)” (Beria et al., 2004).

\section{The Actual Case, Quadrilatero S.p.A.}

The second part of this research essay is focused on the actual case of "Quadrilatero S.p.A" that is a projectdedicated Joint Stock Company. Regione Marche and Regione Umbria are involved in this project. Regione Marche is one of the last eastern regions in Italy without a direct road to the other Italian coast and the Italian capital city. The following Figure 1 shows the two regions involved in the project.

This company involves a lot of authorities of public sectors, among different levels of governance hierarchy, but there are private shareholders too, coming from both Regione Umbria and Regione Marche as highlighted by 


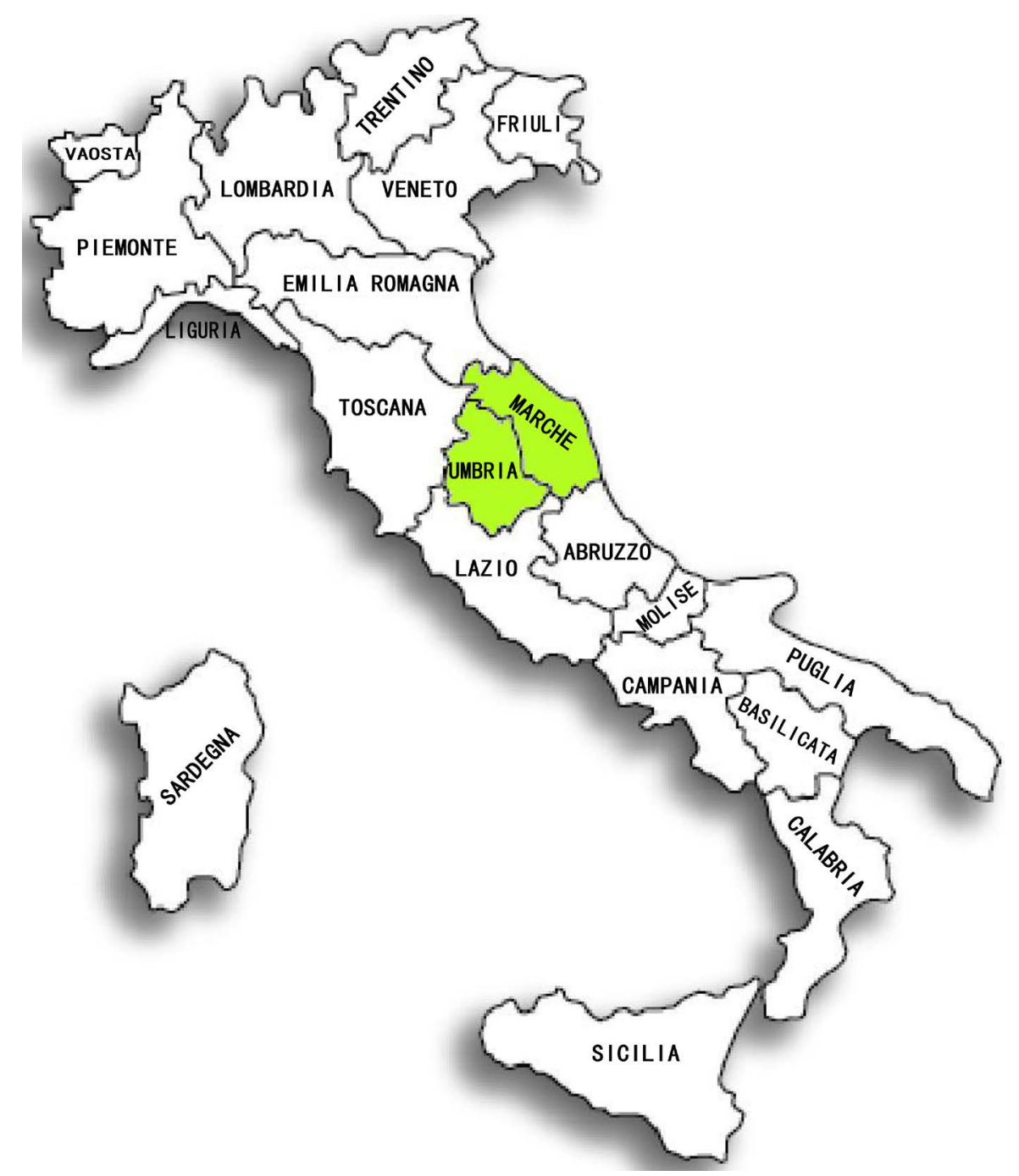

Figure 1. Regione Umbria and Regione Marche (in green).

details (total value of the company: 50 million EUR, around 65 million CAD):

- ANAS S.p.A: 92.382\% (that is expected to take over Quadrilatero S.p.A. during 2016)

- Regione Marche: $2.858 \%$

- Sviluppumbria S.p.A. (joint stock company, 92\% Regione Umbria): $2.400 \%$

- Province of Macerata: $1.016 \%$

- Chamber of commerce of Macerata: $0.500 \%$

- Chamber of commerce of Perugia: $0.500 \%$

- Chamber of commerce of Ancona: 0.284\%

- Province of Perugia: $0.060 \%$

The following Figure 2 shows in a clearer way the division between private and public participation in the project.

The project is addressed to provide two better connections between Regione Marche and Regione Umbria, and within Regione Marche a better connection between the province of Macerata and the province of Ancona. The following map (Figure 3) will be very useful in order to ensure a better comprehension of the project. In addition, seeing the map, we can understand the choice of the name of that company: quadrilatero is an Italian word that means quadrilateral.

Ancona, regional capital city of Marche, and Civitanova Marche, a city of the province of Macerata, are already well connected by the toll highway "A14" (three lanes each direction, speed limit $130 \mathrm{~km} / \mathrm{h}$ ). Ancona area 


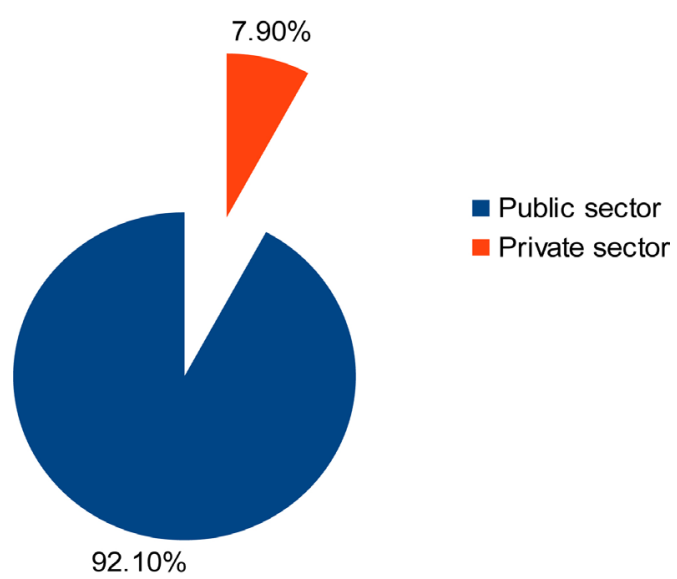

Figure 2. Project Map. Source: Quadrilatero S.p.A. Website.

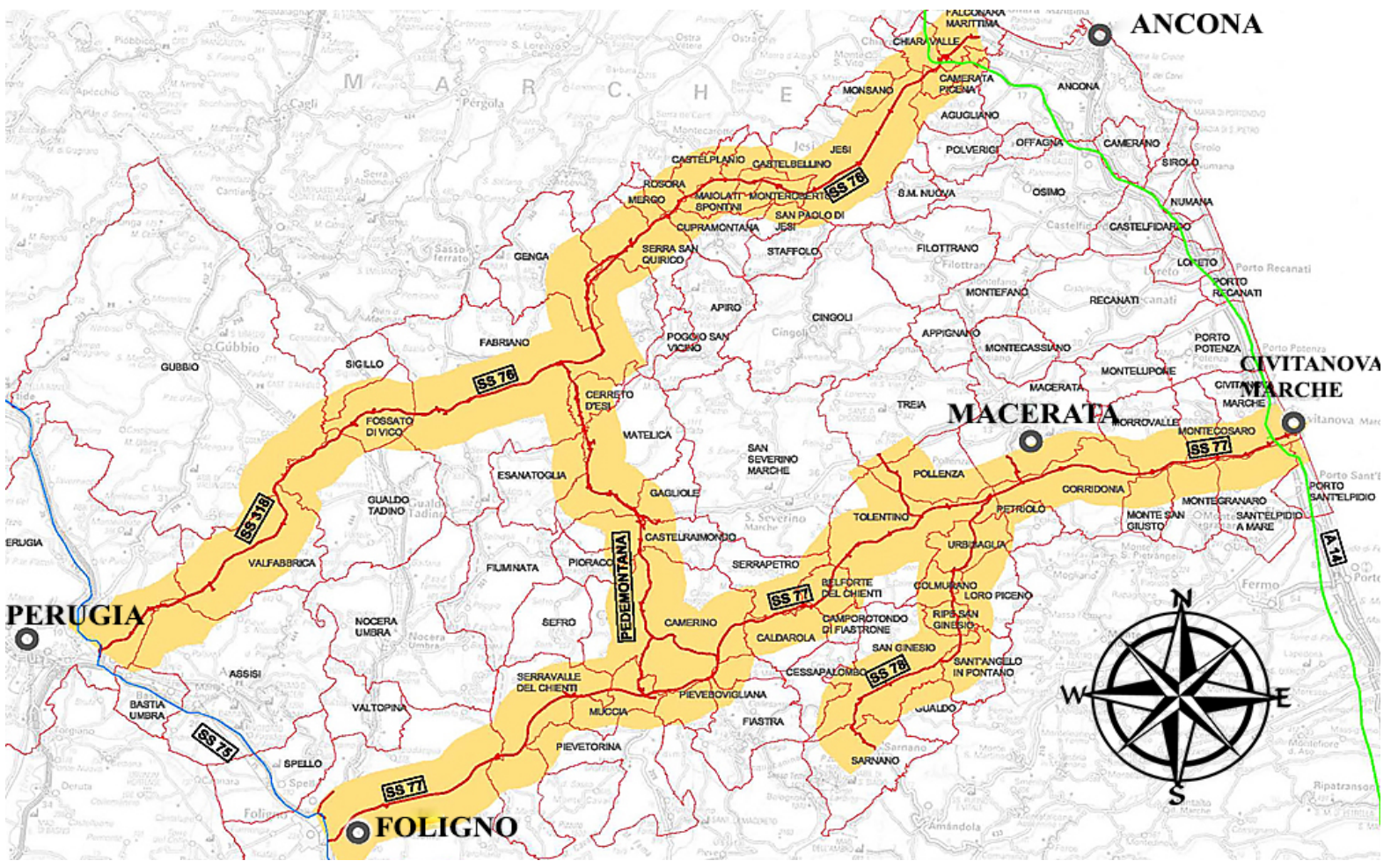

Figure 3. Quadrilatero S.p.A.-Project Map.

is connected to Fabriano area by a free-toll highway (two lanes each direction, speed limit $110 \mathrm{~km} / \mathrm{h}$ ). Civitanova Marche, Macerata and Tolentino are well connected by a free-toll highway (two lanes each direction, speed limit $110 \mathrm{~km} / \mathrm{h}$ ). Perugia and Foligno are connected by a free-toll highway (two lanes each direction, speed limit $110 \mathrm{~km} / \mathrm{h})$. Within the existing network, the project has three goals:

- It wants to provide a better connection between the inner part of the province of Macerata and the inner part of the province of Ancona (Fabriano area).

- It wants to develop the already existing free-toll highways.

- It wants to improve the local road network linked to these two free-toll highways.

The necessity of the project is clear: currently the connection between Regione Marche and Regione Umbria (and its roads directed to the west coast and to Rome) it is clearly unacceptable. Freight trucks, grain carriers and cars have to overcome often-snowy mountain passes in order to reach the other side of Apennine Mountains, a mountain chain extending around 1200 along the length of peninsular Italy: the part of Apennines that divides 
Umbria from Marche is called "Sibillini Mountains”. Province of Ancona and province of Macerata are about 250 - 300 kilometers far from Rome but driving through mountain passes could be an enormous waste of time, and in the field of goods distribution a waste of money for companies. That itinerary can be very dangerous especially for heavy vehicles, because of frequent snowy days, continual hairpin turns and ravines. In addition, small typical mountain villages are very disturbed by that kind of traffic.

The construction is well underway and the project started in 2009 and its completion is scheduled for late 2016: the expected cost is 2,177,260,000 €, around 3 billion CAD (Quadrilatero S.p.A. Website). That project represents a success of the Italian governance hierarchy. Only an effective coordination among Italian state represented by ANAS, regional governments and provincial governments, has permitted a successful involvement of 41 municipalities located in Regione Marche and 7 municipalities located in Umbria. Only a strong cooperation among them has permitted and will permit to face important problems, and especially natural challenges. Areas around the border between Marche and Umbria are highly seismic and are sadly famous for a sequence of violent earthquakes that hit those places in 1997. Therefore, authorities have to monitor the quality of works and they have to ensure that new infrastructures can face that kind of threat. In addition, there is the fundamental need of a low environmental impact because those areas are characterized by the presence of a multitude of national and regional parks. In order to overcome mountains, tunnels and bridges will be built by contractors linked to Quadrilatero S.p.A. Nevertheless, the company will balance the impact of constructions by foresting 1515 hectares of land.

Expected economic impacts related to the construction of these road infrastructures are ambitious especially in terms of regional development. Quadrilatero S.p.A. evaluates, in the first period after the completion of the project, a net growth of GDP of Regione Marche and Regione Umbria equal to 1.8 billion EUR, around 2,3 billion CAD. The company evaluates a stable net growth for the following years equal to 200 million EUR, around 260 million $\mathrm{CAD}$, directly related to the project. In addition, there are expected benefits for the employment: the construction period is employing 90,000 workers and after the completion, there will be 8000 employments directly related to the project. Regional development will be ensured by a simultaneous project called "Aree Leader" oriented to create commercial and productive hubs along these new roads: particularly interesting are a business incubator near Fabriano, an exhibition hub near Ancona, and a productive agroindustrial hub in the area of Camerino.

Regione Marche is highly developed and its economy is export oriented. Even though financial crises hit strongly this region, we can see in the following Figure 4 data related to exports showing a significant growth, since 2012.

This project will allow to tackle the lack of connections within the region and will provide a better link among highly specialized areas; the most interesting hubs involved are the hub of Fabriano that is highly specialized in home appliance (Indesit, Ariston), the area between Macerata and Fermo that is highly specialized in the footwear industry (Tod's), the area between Macerata and Treia that is highly specialized in furniture making (Lube Group, Poltrona Frau). In addition, a road network development will permit to companies within Regione Marche to develop commerce not only, as currently, by using highway A14 along the east coast but also connecting to the most important Italian highway, A1 that goes from Milan to Naples. In the following Table 1, we can see some data in order to understand the value of those companies.

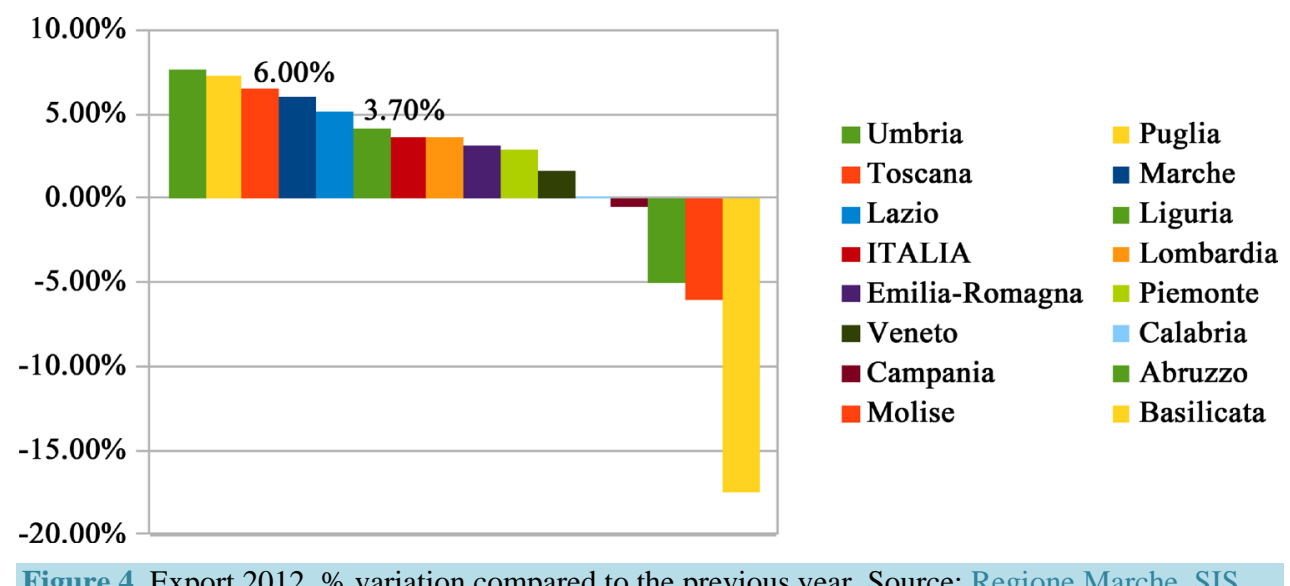


Table 1. Revenues of companies listed in the paper, data of 2014, Source: Balloni \& Iacobucci (2015)-ISTAO.

\begin{tabular}{cc}
\hline Company & REVENUE in $€$ \\
\hline INDESIT COMPANY SPA & $2,612,100,000$ \\
ARISTON THERMO SPA & $1,342,363,000$ \\
TOD’S SPA & $965,532,000$ \\
POLTRONA FRAU SPA & $286,085,000$ \\
LUBE HOLDING SRL (SRL, in English LLC) & $156,485,000$ \\
LUBE INDUSTRIES SRL & $150,525,000$ \\
\hline
\end{tabular}

\section{Conclusion}

As we have seen, even with improper delay, various levels of governance have been able not only to reach a successful coordination but also to obtain the cooperation of private authorities and companies. In this way, they have been able to launch a project strongly required by the exigencies of a highly developed region with enormous ambitions for the future. Infrastructure development of a dynamic territory characterized by these conditions produces a double positive result: improved conditions for mobility of inhabitants of those regions and, as already mentioned in the introduction, the creation of an important flywheel for regional companies.

\section{References}

Balloni, V., \& Iacobucci, D. (2015). Annual Ranking of the Most Important Companies in Regione Marche. ISTAO Business School, Ancona.

Beria, P., Brambilla, M., \& Erba, S. (2004). The Italian Expenditure in Transport Infrastructure. University Library of Munich, Germany.

Beria, P., Grimaldi, R., \& Laurino, A. (2010). Financing Transport Infrastructure Projects in Italy: A Critical Analysis of the Main Approaches. General Proceedings of the 12th World Conference on Transport Research Society, Lisbon, 2010, 116.

Ponti, M. (2005). National Systems of Transport Infrastructure Planning: The Case of Italy. Report of the One Hundred and Twenty Eighth Round Table on Transport Economics.

Quadrilatero S.p.A Website. The Project. http://www.quadrilaterospa.it/docs/ilprogetto/ilprogetto.asp

Regione Marche Website, Statistical Information System.

http://statistica.regione.marche.it/LinkClick.aspx?fileticket=yKA41tzgDZc\%3d\&tabid=36 